\title{
Breast Self-Examination Practice and Its Associated Factor among the Women of Reproductive Age of Rapti Sonari Rural Municipality, Banke District
}

\author{
Prativa Gyawali ${ }^{1}$, Samjhana Gautam ${ }^{2}$ \\ ${ }^{1}$ Bachelor of Public Health, Purbanchal University, Nepal \\ ${ }^{2}$ Project Manager, Society Development \& Promotion Center (SDPC), Nepalgunj, Banke, Nepal \\ Corresponding Author: Prativa Gyawali
}

\begin{abstract}
Introduction: Breast self-examination (BSE) is a screening method used to detect early breast cancer which involves the women herself looking at and feeling each breast for possible lumps, distortions or swelling. BES is a simple, inexpensive, non-invasive procedure which helps a woman to know her breast and allows her to detect changes in the breast; such as breast masses or lumps.

Method: Descriptive cross sectional study design was used to assess the Practice on breast selfexamination and its associated factors because the use of descriptive design for the study gathers data directly from respondents from their natural environment for the purpose of studying their practice level regarding to Breast Self-Examination. This study followed quantitative study. Quantitative study was used to identify practice on Breast self-examination and its factors association.

Result: The main findings of the study showed that $12.2 \%$ have practice the breast self-examination. Source of information regarding BSE among respondents were found $72.5 \%$ from health professional and mass media $6.5 \%$. The researcher's study finding revel that knowledge regarding BSE was found adequate in $44.3 \%$ of respondents. Research study also illustrates that only $19.6 \%$ have examined their breast. $50.8 \%$ of the respondent state lack of knowledge and $36.7 \%$ respondent stated lack of self-confidence level for not performing BSE. 8.3\% reported that they practice it occasionally and remaining $0.4 \%$ and $3.5 \%$ practice monthly and weekly respectively. Similarly, $85.7 \%$ didn't find any abnormalities. Whereas $14.3 \%$ have notice, after seen abnormalities $100 \%$ of them have visit hospital for check-up. Only $17.8 \%$ have informed about family history among 28 . And only $7.2 \%$ of them follow the periodic health check-up. Whereas, $14.3 \%$ had done annual check-up and $85.7 \%$ had not done. In this it was found that there was no association between the different factors such as age, education, occupation, ethnicity and other socio-demographic factor of the respondent. Lack of awareness among the women about BSE was the major issue for not practicing Breast selfexamination in a community level.

Conclusion: The finding of the study concluded that practice regarding BSE is inadequate and there is no any association between practice and demographic status. The study suggested that upgrade the knowledge of BSE and increase the practice of BSE. Thus, various educational intervention/awareness programs should be conducted in a community level as for self-preventive practice.
\end{abstract}

Keywords: Breast self-examination

\section{INTRODUCTION}

Breast self-examination (BSE) is a screening method used to detect early breast cancer which involves the women herself looking at and feeling each breast for possible lumps, distortions or swelling. BES is a simple, inexpensive, non-invasive procedure which helps a woman to know her breast and allows her to detect changes 
Prativa Gyawali et.al. Breast self-examination practice and its associated factor among the women of reproductive age of Rapti Sonari Rural Municipality, Banke District.

in the breast; such as breast masses or lumps (burke et al., 2007)

Breast cancer is the second most common malignancy among Nepalese women. Breast cancer places a substantial burden on the Nepalese healthcare system, but information regarding the number of women living with breast cancer is not well recorded. In countries with lower levels of resources such as Nepal, breast cancers are commonly diagnosed at late stages and women may receive inadequate treatment, pain relief or palliative care. According to GLOBOCAN 2012, an estimated 1,700 new breast cancer cases were diagnosed in Nepal in 2012, with an age standardized rate (ASR) of 13.7 new cases per 100,000 women, while 870 fatalities in women occurred, with an ASR of 7.2 fatalities per 100,000 women.

According to NATIONAL BREAST CANCER FOUNDATION, INC One in eight women in the United States will be diagnosed with breast cancer in her lifetime. Breast cancer is the most diagnosed cancer in women. Breast cancer is the second leading cause of cancer death among women. Each year it is estimated that over 252,710 women in the United States will be diagnosed with breast cancer and more than 40,500 will die. Although breast cancer in men is rare, an estimated 2,470 men will be diagnosed with breast cancer and approximately 460 will die each year. On average, every 2 minutes a woman is diagnosed with breast cancer and 1 woman will die of breast cancer every 13 minutes. Over 3.3 million breast cancer survivors are alive in the United States today.

Breast cancer is a malignant tumor that has developed from cells of the breast. In its early stages breast cancer has few symptoms. However, the earlier that breast cancer is detected, the more treatment option are available and the greater the likelihood of recovery. It is estimated that about $10-20 \%$ of breast cancer that are detected in a self-exam or a clinical breast exam are not detectable by $\mathrm{x}$-ray-film mammography. It is particularly important for women at increased risk for breast cancer to perform self-exam. It has generally been recommended that all women perform monthly breast-exams, beginning in their $20 \mathrm{~s}$ and continuing throughout life. Similarly, they should also be aware of benefits of self-exams.

A descriptive cross sectional study conducted among 220 female students to asses knowledge about breast cancer and breast self-examination in Dharan BPKIHS shows that overall level of knowledge was found to be moderately adequate among all, however practice regarding BSE among them were found inadequate in which embarrassment, lack of privacy, unpleasant feelings were addressed for low practice. (Parajuli P. December 2010)

Research on the practice of breast self-examination and its associated factor among the women in a community level may help educational planner and to prevent various breast cancer cases in Nepal and also increase the awareness. The aim of the study is to find out the practice level existing in the community on Breast Selfexamination. Therefore, as per above scenario, the increasing trend in breast cancer is suggesting having a knowledge and practice of breast self-examination which was found inadequate among reproductive women group according to the most of research studies. We hope this study provide baseline data to assist health planner in developing evidence-based strategies for the further study in future to increase the practice and decline the rate of Breast cancer.

\section{NEED FOR STUDY}

Breast cancer is the most common malignancy affecting women with more than one million worldwide. Breast cancer among women is rising fast in Nepal and becoming more fatal as women go to hospital only when the cancer has progressed to the third stage. Breast cancer is second most diagnosed cancer on Nepal after cervical cancer. Therefore, problem of 
Prativa Gyawali et.al. Breast self-examination practice and its associated factor among the women of reproductive age of Rapti Sonari Rural Municipality, Banke District.

breast cancer is in an increasing trend in the developing countries that includes Nepal also.

Breast Self-examination is one of the most convenient ways to detect the breast cancer at its initial stage so that treatment can be proceed. The various report and findings identify that it is necessary to increase awareness on the knowledge and practice of Breast self-self-examination among the reproductive age women group in a community level to prevent increasing rate of breast cancer in an initial stage of life. Furthermore, a smaller number of researches had been conducted on the topic breast self-examination. So that this study provides the baseline information and awareness for the further research study regarding breast self-examination. Thus, I felt necessity to do study in practice and its associated factor among the women of reproductive age group.

\section{Conceptual Framework}

Conceptual framework of practice and its associated factor of breast self- examination shows that the conceptual framework of this research study highlights the dependent and independent variables of the study such as Socio-demographic factors like Age, Marital status, Level of education, Ethnicity, Religion ,Socio-economic factor, Occupation. Knowledge regarding breast self-examination, Source of information exposure to media (radio, television) and Periodic health check-up. Throughput consists of the process of assessment of the level of breast selfexamination practice and its associated includes the assessment of adequate practice early detection of breast cancer, management of breast cancer. Inadequate practice delay diagnosis of breast cancer, incidence, risk factors, sign and symptom, management and prevention of breast cancer. The outcome might be positive or negative. Positive outcome refers to adequate level of practice on breast selfexamination and negative results refers to inadequate practice.

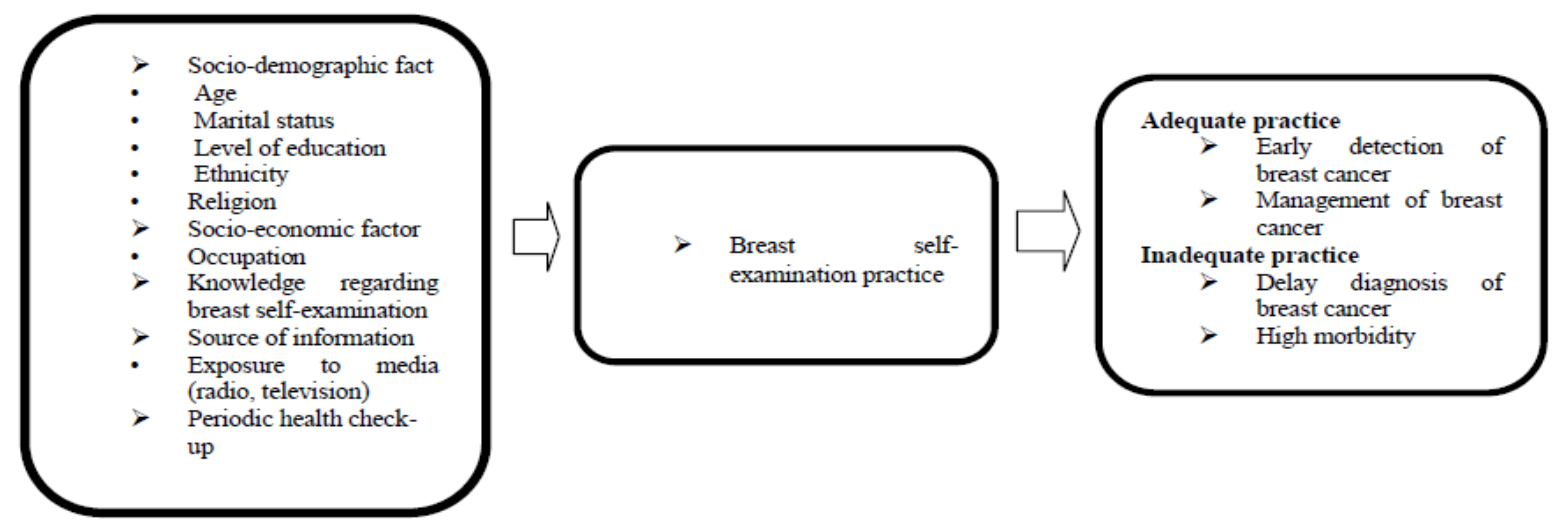

METHODS AND MATERIALS

Research design: Descriptive crosssectional study design was used

Study area: The area selected for the research was Rapti Sonari Municipality, Banke District. As this is a rural municipality and enough number of women were available, so this place was selected.

Study Population: The study population was women of reproductive age group.
Sample size: In article of malignant neoplasm burden in Nepal-data from the seven major cancers service hospitals in $2012,16.3 \%$ were the case of breast cancer. So prevalence rate $(\mathrm{p})$ is $16.3 \%$, marginal error (d) is 0.05 and confidence interval of $95 \%(1.96)$

It was calculated using the formula,

$$
\mathrm{n}=\frac{\mathrm{z}^{2} \mathrm{p}(1-\mathrm{p})}{\mathrm{d}^{2}}
$$

So, 
Prativa Gyawali et.al. Breast self-examination practice and its associated factor among the women of reproductive age of Rapti Sonari Rural Municipality, Banke District.

Prevalence of emergency contraceptives (p) $=16.3 \%=16.3 / 100=0.163$

Level of significance $(\alpha)=95 \%$ i.e. 1.96

Maximum allowable error $(\mathrm{d})=0.05$

$\mathrm{q}=1-\mathrm{p}=1-0.163=0.837$

So,

$$
\begin{aligned}
\mathrm{n} & =\frac{\mathrm{z}^{2} \mathrm{p}(1-\mathrm{p})}{\mathrm{d}^{2}} \\
& =\frac{3.8416^{*} 0.163 *(1-0.163)}{(0.05) 2} \\
& =209.36
\end{aligned}
$$

Substituting value in above equation, the sample size was found to be 209.36

Again, sample size $(\mathrm{n})=209.36+10 \%$ of 209.36

$=209.36+0.1 * 209.36$

$=230$

Therefore, considering 10\% non- response rate, the final sample size was determined to be 230 .

\section{Sampling technique}

In this study the district was chosen by convenient sampling technique similarly rural municipality was also chosen by convenient sampling technique and ward number was selected by simple random sampling or lottery method likewise, respondents were chosen by census.

\section{Pretesting of tool}

Pretesting was conducted prior to research in a sample population with similar characteristic. Pretesting of schedule was done in $10 \%$ population of total calculated sample in community. Necessary modification to the fault and error in the tools was made after pretesting.

\section{Ethical consideration}

At first, a letter of approval was taken from Om Health Campus for the study purpose. Then ethical clearance approval was taken from NHRC Ethical Clearance Board. Similarly, a letter of approval was taken from Nepalgunj Sub-municipality of Banke district for the collection. Most importantly, before beginning the data collection, an informed verbal consent was taken from each respondent. Respondents were not forced to give information against their will. Information collected for the research was not used for any other purpose with proper maintenance of respondent's privacy and confidentiality.

\section{Procedure for data collection:}

Data collection was primary source.

Data collection method was selfadministration questionnaire. At first approval letter was taken from the Om Health Campus which was submitted to the Rapti Sonari rural municipality. After their acceptance of letter, second approval letter was provided by Rapti Sonari rural municipality data collection procedure was conducted. Objectives of study were explained to every individual respondent. 15-20 minutes was taken to take their interview and fill the questionnaire. Finally, the data was collected.

\section{RESULTS}

The final findings of the study are:

$\checkmark$ Data related to demographic characteristics of the respondent.

$\checkmark$ Data related to Practice about Breast self-examination.

$\checkmark$ Data related to association between socio-demographic characteristics and practice of Breast self-examination

Table 1 shows that among 230 respondents, majority were of age between (31-40) $36.08 \%$. Similarly, $56.08 \%$ of the respondents were literate and $43.91 \%$ were Illiterate. Among all the respondent $90.9 \%$ of respondent where married. More than half of the respondent54.3\% had (1-2) number of children. Where, $62.6 \%$ of them were housewife, furthermore, $46 \%, 2.2 \%$, $4.3 \%, 1.7 \%$ and $9.1 \%$ were engaged in agriculture, business, private job and government job and student by their professions respectively. Among all 99.9\% were Hindu and remaining 0.4 were Buddhist. The ethnicity of respondent is found to be Brahmin 34.8\%, Dalit 1.7\%, Tharu $32.8 \%$ and Janajti $31.30 \%$. 
Prativa Gyawali et.al. Breast self-examination practice and its associated factor among the women of reproductive age of Rapti Sonari Rural Municipality, Banke District.

\begin{tabular}{|l|l|l|}
\hline $\begin{array}{l}\text { Table 1: Respondent's Socio- demographic characteristics } \\
\text { information (n= 230) }\end{array}$ \\
\hline $\begin{array}{l}\text { Socio- demographic } \\
\text { variables }\end{array}$ & Frequency (n) & $\begin{array}{l}\text { Percentage } \\
(\%)\end{array}$ \\
\hline Age categories & & \\
\hline Less than 20 & 21 & 9.13 \\
\hline $21-30$ & 67 & 29.13 \\
\hline $31-40$ & 83 & 36.08 \\
\hline $41-50$ & 59 & 25.65 \\
\hline Educational status & & \\
\hline Illiterate & 101 & 43.91 \\
\hline Literate & 129 & 56.08 \\
\hline Religious status & & \\
\hline Hindu & 229 & 99.6 \\
\hline Buddhist & 1 & 0.4 \\
\hline Ethnicity & & \\
\hline Brahmin/Chhetri & 80 & 34.8 \\
\hline Dalit & 4 & 1.7 \\
\hline Tharu & 74 & 32.8 \\
\hline Janajati & 72 & 31.30 \\
\hline Marital status & & \\
\hline Married & 209 & 90.9 \\
Unmarried & 15 & 6.5 \\
\hline Widow & 4 & 1.7 \\
\hline Divorced & 2 & 0.9 \\
\hline Number of children & & \\
\hline No child & 23 & 10.1 \\
\hline 1-2 & 125 & 54.3 \\
\hline 3-4 & 63 & 27.6 \\
More than 4 & 19 & 8.2 \\
\hline Source of income & & \\
\hline Agriculture & 46 & 20.0 \\
\hline Business & 5 & 2.2 \\
\hline Government job & 4 & 1.7 \\
\hline Private job & 10 & 4.3 \\
\hline Housewife & 144 & 62.6 \\
\hline Student & 21 & 9.1 \\
\hline & & \\
\hline
\end{tabular}

Table 2 shows that among 230 respondents, only $19.6 \%$ have known about examination of Breast self-examination .The major sources of information they got to know about BSE was health facilities which was $72.5 \%$ likewise $7.8 \%, 7.8 \%$, $6.5 \%$ and $0.9 \%$ know from self-education ,peers-relatives, mass media and family respectively. And $12.2 \%$ of respondent state that they have practices the breast selfexamination. Where $50.8 \%$ of respondent stated lack of knowledge and $36.7 \%$ of respondent stated lack of self-confidence level for not performing Breast selfexamination among 185 respondents. Among 28 numbers of respondents who state that they perform BSE, $8.3 \%$ reported that they practice it occasionally and remaining $0.4 \%$ and $3.5 \%$ practice monthly and weekly respectively.
Table 2 Practice on breast self-examination $(\mathrm{n}=\mathbf{2 3 0})$

\begin{tabular}{|l|l|l|}
\hline Characteristics & $\begin{array}{l}\text { Frequency } \\
\text { (n) }\end{array}$ & Percentage (\%) \\
\hline $\begin{array}{l}\text { Know about Breast self- } \\
\text { examination }\end{array}$ & & \\
\hline Yes & 102 & 44.3 \\
\hline No & 128 & 55.7 \\
\hline Source of information & & $*$ \\
\hline Mass media & 15 & 6.5 \\
\hline Health Facilities & 74 & 72.5 \\
\hline Peers-relatives & 8 & 7.8 \\
\hline Self-education & 8 & 7.8 \\
\hline Family & 2 & 0.9 \\
\hline Ever examined breast & & 19.6 \\
\hline Yes & 45 & 80.4 \\
\hline No & 185 & $*$ \\
\hline $\begin{array}{l}\text { Reason for not examined } \\
\text { breast(n=185) }\end{array}$ & & 36.7 \\
\hline $\begin{array}{l}\text { Lack of self-confidence } \\
\text { level }\end{array}$ & 68 & 50.8 \\
\hline Lack of knowledge & 117 & \\
\hline $\begin{array}{l}\text { Reason for examined } \\
\text { breast(n=45) }\end{array}$ & & 16.5 \\
\hline $\begin{array}{l}\text { To protect from Breast } \\
\text { cancer }\end{array}$ & 38 & 2.2 \\
\hline Health services suggestion & 5 & 18.3 \\
\hline Peer-Family & 42 & 18.3 \\
\hline Others reason & 42 & 8.3 \\
\hline $\begin{array}{l}\text { Do you practice it regular } \\
\text { (n=230) }\end{array}$ & & \\
\hline Yes & 28 & 12.2 \\
\hline No & 19 & \\
\hline $\begin{array}{l}\text { How often do you perform } \\
\text { BSE (n=28) }\end{array}$ & & \\
\hline Monthly & 1 & \\
\hline Weekly & & \\
\hline Occasionally & & \\
\hline
\end{tabular}

(*Multiple response set)

Table 3 Practice on breast self-examination $(\mathrm{n}=\mathbf{2 8})$

\begin{tabular}{|l|l|l|}
\hline Characteristics & $\begin{array}{l}\text { Frequency } \\
(\mathbf{n})\end{array}$ & $\begin{array}{l}\text { Percentage } \\
(\%)\end{array}$ \\
\hline Any abnormalities & 4 & \\
\hline Yes & 4 & 14.3 \\
\hline No & 24 & 85.7 \\
\hline $\begin{array}{l}\text { If yes, what have you notice } \\
\text { * }\end{array}$ & & \\
\hline Lumps & 1 & 4 \\
\hline Pain & 4 & 1.7 \\
\hline Discharge of fluid & 3 & 1.3 \\
\hline Redness after seen & 3 & 1.3 \\
\hline $\begin{array}{l}\text { Action taken } \\
\text { symptoms }\end{array}$ & & \\
\hline Hospital & 4 & 100 \\
\hline Any family history (n=28) & & \\
\hline Yes & 5 & 17.8 \\
\hline No & 23 & 82.14 \\
\hline $\begin{array}{l}\text { Periodic Health Check- Up } \\
\text { (n=28) }\end{array}$ & & \\
\hline Yes & 2 & 7.2 \\
\hline No & 26 & 92.8 \\
\hline Annual Health Check-Up & & \\
\hline Yes & 4 & 14.3 \\
\hline No & 24 & 85.7 \\
\hline
\end{tabular}

Table 3 Shows that, $85.7 \%$ didn't find any abnormalities. Where, $14.3 \%$ have notice some kind of abnormalities. Feeling of lumps in breast was the major symptoms which was $4 \%$ likewise pain, fluid discharge 
Prativa Gyawali et.al. Breast self-examination practice and its associated factor among the women of reproductive age of Rapti Sonari Rural Municipality, Banke District.

and redness was 1.7\%, $1.3 \%, 1.3 \%$ respectively. After seen abnormalities $100 \%$ of the have visit hospital. Only $17.8 \%$ have informed about family history of breast cancer among. And only $7.2 \%$ of them follow the periodic health check up. Whereas, $14.3 \%$ had done annual check-up and $85.7 \%$ had not done.

Table 3: Associated of practice with socio-demographic variables $(\mathbf{n}=\mathbf{2 3 0})$

\begin{tabular}{|c|c|c|c|}
\hline \multirow[t]{2}{*}{ Characteristics } & \multicolumn{2}{|c|}{ Frequency(n) } & \multirow{2}{*}{$\begin{array}{l}\text { P- } \\
\text { value }\end{array}$} \\
\hline & Yes & No & \\
\hline \multicolumn{4}{|l|}{ Age categories } \\
\hline Less than 20 & $2(7.1 \%)$ & $11(5.4 \%)$ & \\
\hline $21-30$ & $7(25 \%)$ & $56(27.7 \%)$ & 0.53 \\
\hline $31-40$ & $10(35 \%)$ & $93(46.3 \%)$ & \\
\hline $41-50$ & $9(32 \%)$ & $42(20.7 \%)$ & \\
\hline \multicolumn{4}{|l|}{ Religious status } \\
\hline Hindu & $28(100 \%)$ & $201(99.5 \%)$ & 0.709 \\
\hline Buddhist & $0(0.0 \%)$ & $1(0.5 \%)$ & \\
\hline \multicolumn{4}{|l|}{ Ethnicity } \\
\hline Brahmin/Chhetri & $15(53.6 \%)$ & $65(32.2 \%)$ & \\
\hline Tharu / madeshi & $4(14.3 \%)$ & $70(34.7 \%)$ & 0.168 \\
\hline Dalit & $1(3.6 \%)$ & $3(1.5 \%)$ & \\
\hline Janajati & $8(28.4 \%)$ & $64(31.7 \%)$ & \\
\hline \multicolumn{4}{|l|}{ Marital status } \\
\hline Married & $25(89.3 \%)$ & $184(91.1 \%)$ & \\
\hline Unmarried & $1(3.6 \%)$ & $14(6.9 \%)$ & 0.109 \\
\hline Widow & $2(7.1 \%)$ & $2(1.0 \%)$ & \\
\hline Divorced & $0(0.0 \%)$ & $2(1.0 \%)$ & \\
\hline \multicolumn{4}{|l|}{ Education status } \\
\hline Literate & $22(78.6 \%)$ & $107(52.9 \%)$ & 0.083 \\
\hline Illiterate & $6(21.4 \%)$ & $95(47.1 \%)$ & \\
\hline \multicolumn{4}{|c|}{$\begin{array}{l}\text { Occupation } \\
\text { respondent }\end{array}$} \\
\hline Agriculture & $7(25.0 \%)$ & $39(19.3 \%)$ & \\
\hline Business & $0(0.0 \%)$ & $5(2.5 \%)$ & \\
\hline Government job & $1(3.6 \%)$ & $3(1.5 \%)$ & 0.078 \\
\hline Private job & $4(14.3 \%)$ & $6(3.0 \%)$ & \\
\hline House wife & $14(50.0 \%)$ & $130(64.4 \%)$ & \\
\hline Student & $2(7.1 \%)$ & $19(9.4 \%)$ & \\
\hline \multicolumn{4}{|l|}{ Number of child } \\
\hline $1-2$ & $21(75.0 \%)$ & $104(52.0 \%)$ & \\
\hline $3-4$ & $5(17.9 \%)$ & $58(29.0 \%)$ & 0.106 \\
\hline More than 4 & $0(0.0 \%)$ & $19(9.5 \%)$ & \\
\hline No child & $2(7.1 \%)$ & $21(10.1 \%)$ & \\
\hline \multicolumn{4}{|l|}{ Menopause status } \\
\hline No & $28(100.0 \%)$ & $202(100.0 \%)$ & \\
\hline
\end{tabular}

Table 3 represents that there is no association between breast self-examination practice and its associated factors because $p$ value is greater than 0.05 .

\section{DISCUSSION AND CONCLUSION}

The primary aim of this study is to assess the practice on breast selfexamination and to find its factor associated with it .The main findings of the study showed that $12.2 \%$ have practice the breast self-examination which was similar to the study Butwal sub-metropolitan city conduct among the 219 women of reproductive age, where the result was only $19.2 \%$ of women have practice BSE. In the researcher's study, source of information regarding BSE among respondents were found $72.5 \%$ from health professional and mass media $6.5 \%$ which was contrast to the study conducted at Ahmadu bello university Zaria, northwestern Nigeria, in 2009 where source of information about BSE among respondents, was found to be most common through mass media i.e. $45 \%$ and health professional was $32.2 \%$ respectively. The researcher's study finding revel that knowledge regarding BSE was found adequate in $44.3 \%$ of respondents and practice was found $12.2 \%$ which was supported by a study conducted in the Muslim female workers at a hazelnut factory in Urdu city where only $26.2 \%$ had knowledge of BSE and only $4.3 \%$ practice BSE. Thus, both studies are quite similar to each other. Assessing practice and associated factor of BSE among female student in Ethiopia where lack of knowledge on how to perform BSE was cited as the main reason for not practicing BSE. And having a perception that BSE is important and useful to detect breast cancer were significant predictors of practice of BSE, this study revealed that most of the participant had low knowledge and practice of BSE which is similar to my studies.

This research study also illustrates that only $19.6 \%$ have examined their breast. $50.8 \%$ of the respondent state lack of knowledge and $36.7 \%$ respondent stated lack of self-confidence level for not performing BSE. $8.3 \%$ reported that they practice it occasionally and remaining $0.4 \%$ and $3.5 \%$ practice monthly and weekly respectively. Similarly, $85.7 \%$ didn't find any abnormalities. Whereas $14.3 \%$ have notice, after seen abnormalities $100 \%$ of them have visit hospital for check-up. Only $17.8 \%$ have informed about family history among 28. And only $7.2 \%$ of them follow the periodic health check-up. Whereas, 
Prativa Gyawali et.al. Breast self-examination practice and its associated factor among the women of reproductive age of Rapti Sonari Rural Municipality, Banke District.

$14.3 \%$ had done annual check-up and $85.7 \%$ had not done.

In this it was found that there was no association between the different factors such as age, education, occupation, ethnicity and other socio-demographic factor of the respondent. Lack of awareness among the women about BSE was the major issue for not practicing Breast self-examination in a community level.

\section{CONCLUSION}

A descriptive type of study was conducted on practice of breast selfexamination and its associated factors among the women of reproductive age group at Rapti Sonari rural municipality, Banke district. The finding of the study concluded that practice regarding BSE is inadequate and there is not any association between practice and demographic status. The study suggested that upgrade the knowledge of BSE and increase the practice of BSE. Thus, various educational intervention/awareness programs should be conducted in a community level as for selfpreventive practice.

\section{Recommendation}

- A similar study can be conducted by including interventional program.

- A comparative study can be carried out.

- A similar study can be undertaken by adopting an experimental research.

- Various educational intervention/awareness programs could be conducted in a community level as for self-preventive practice.

\section{Acknowledgement: None}

\section{Conflict of Interest: None}

\section{Source of Funding: None}

\section{Ethical Approval: Approved}

\section{REFERENCES}

1. Avci IA. Factors associated with breast selfexamination practices and beliefs in female workers at a Muslim community. European journal of oncology nursing. 2008; 12(2): 127-33.

2. Petro-Nustus W, Mikhail BI. Factors associated with breast self-examination among Jordanian women. Public Health Nursing. 2002;19(4):263-71.

3. Thomas DB, Gao DL, Ray RM, Wang WW, Allison CJ, Chen FL, et al. Randomized Trial of Breast Self-Examination in Shanghai: Final Results. JNCI: Journal of the National Cancer Institute. 2002; 94(19):1445-57.

4. Gwarzo U, Sabitu K, Idris S. Knowledge and practice of breast self-examination among female undergraduate students. Annals of African medicine. 2009;8(1).

5. Foster Jr RS, Lang SP, Costanza MC, Worden JK, Haines CR, Yates JW. Breast self-examination practices and breast-cancer stage. New England Journal of Medicine. 1978;299(6):265-70.

6. Budden L. Registered nurses' breast selfexamination practice and teaching to female clients. Journal of Community Health Nursing. 1998;15(2):101-12.

7. Champion VL. Relationship of age to factors influencing breast self-examination practice. Health Care for Women International. 1992;13(1):1-9.

8. Birhane $\mathrm{K}$, Alemayehu $\mathrm{M}$, Anawte $\mathrm{B}$, Gebremariyam G, Daniel R, Addis S, et al. Practices of breast self-examination and associated factors among female Debre Berhan University students. International journal of breast cancer. 2017;2017.

9. Naghibi SA, Shojaizadeh D, Montazeri A, Cherati JY. Sociocultural factors associated with breast self-examination among Iranian women. Acta Medica Iranica. 2015:62-8.

10. Secginli S, Nahcivan NO. Factors associated with breast cancer screening behaviours in a sample of Turkish women: a questionnaire survey. International journal of nursing studies. 2006;43(2):161-71.

11. Nde FP, Assob JCN, Kwenti TE, Njunda AL, Tainenbe TRG. Knowledge, attitude and practice of breast self-examination among female undergraduate students in the University of Buea. BMC Research Notes. 2015;8(1):43.

12. Al-Naggar RA, Bobryshev YV, Al-Jashamy K. Practice of breast self-examination among women in Malaysia. Asian Pacific 
Prativa Gyawali et.al. Breast self-examination practice and its associated factor among the women of reproductive age of Rapti Sonari Rural Municipality, Banke District.

Journal of Cancer Prevention. 2012;13(8): 3829-33.

13. Ng KK, Fung SY, Chow LW. Practice of breast self-examination among high risk Chinese women in Hong Kong. Chinese medical journal. 2000;113(12):1100-3.

14. Foxall MJ, Barron CR, Houfek J. Ethnic differences in breast self-examination practice and health beliefs. Journal of advanced nursing. 1998;27(2):419-28.

15. Petro-Nustus W, Mikhail BI. Factors associated with breast self-examination among Jordanian women. Public health nursing (Boston, Mass). 2002;19(4):263-71.

16. Giri M, Giri M, Thapa RJ, Upreti B, Pariyar B. Breast Cancer in Nepal: Current status and future directions. Biomed Rep.
2018;8(4):325-329.

doi:10.3892/br.2018.1057

17. World Health Organization. 2019.

18. Marahatta, S., \& Sharma, S. (2018). Knowledge and practice of breast self examination among women of reproductive age in Butwal Sub Metropolitan City. Journal of Manmohan Memorial Institute of Health Sciences, 4(1), 117-129.

How to cite this article: Gyawali P, Gautam S. Breast self-examination practice and its associated factor among the women of reproductive age of Rapti Sonari Rural Municipality, Banke District. Int $J$ Health Sci Res. 2021; 11(4): 75-82. DOI: https://doi.org/ 10.52403/ijhsr.20210410 